\title{
Impact Of Self Help Groups On Women Empowerment: A Study With Reference To Women Self Help Groups In Aurangabad District
}

\author{
Aparna Bhonde-Saraf \\ Department of Commerce \\ Maulana Azad College, \\ Maharashtra State
}

\begin{abstract}
Microfinance is the most experimented philosophy in today's era. It has infact become a strategic tool for financial inclusion as well. The quantitative growth of microfinance in India mainly through Self Help Groups (SHG) is quiet evident from various studies and reports. Self Help Groups are emerging as a popular vehicle of microfinance. Substantial majority of these groups are women SHGs. In India of more than 61 lakhs of SHGs formed under the NABARD's SHG-Bank Linkage programme, almost $83 \%$ are women SHGs. They are used largely for poverty alleviation. However, various studies reveal that SHGs can supplement empowerment equally. SHGs are providing financial orientation and benefits to the participants. Obviously, this leads to economic empowerment of the members. In addition the group mechanism is assumed to be useful for social empowerment also. The dynamics of this philosophy is studied recently with some positive results.

An attempt is made to understand the impact of SHGs on women empowerment. The study also focuses on examining the role of certain factors (influencers) in affecting empowerment.
\end{abstract}

\section{تلخيص مقالم}

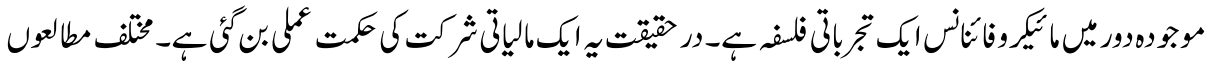

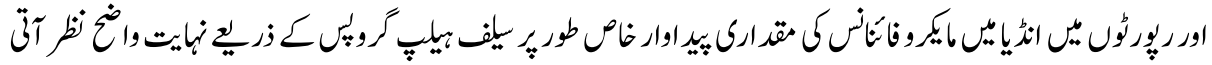

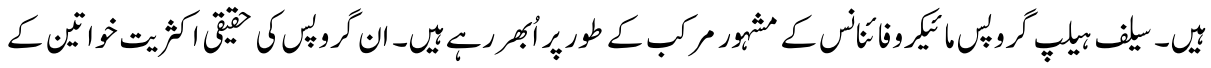

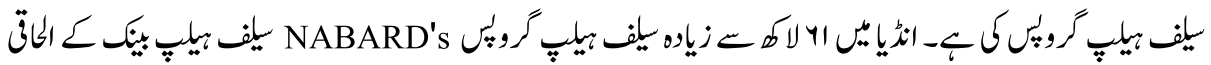

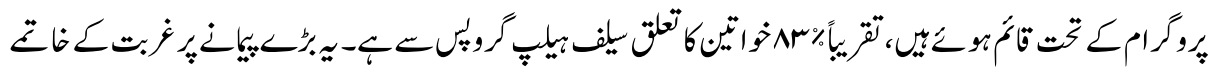

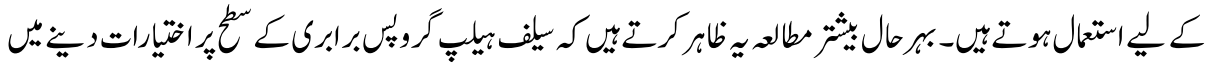

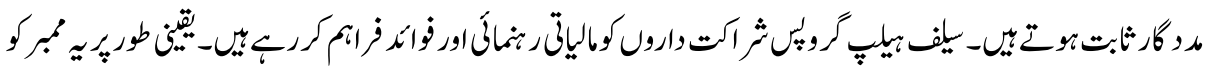

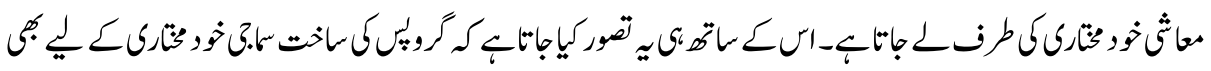

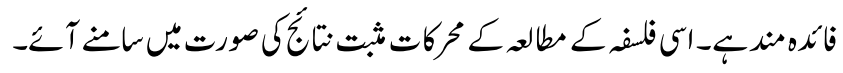

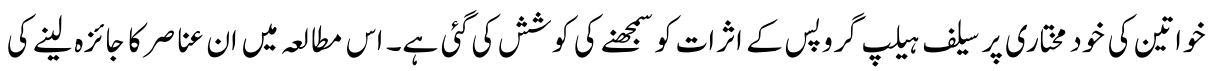

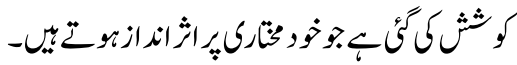


Key words: Microfinance, Self Help Groups, Women Empowerment

\section{Introduction}

Microfinance is the most experimented philosophy in today's era. It has infact become a strategic tool for financial inclusion as well. The quantitative growth of microfinance in India mainly through Self Help Groups is quiet evident from various studies and reports. Microfinance is paving it's ways through a lot of challenges. Reaching the target population in the appropriate perspective is one such challenge.

Gender equality and gender empowerment seem to be the key words of any development activity in today's date. Since independence, India has come a long way. Life of Indian population especially the female population seems to be witnessing positive change in recent decades. Hence it was felt necessary to assess the impact of Self Help Groups in the empowerment of women. With this objective the researcher undertook a study in Aurangabad district of Marathwada.

\section{Statement of Problem}

Microfinance is observed to be an important contribution towards poverty alleviation. At the same time it is also considered to be having the potential of empowering the participants. However, the extent to which it can empower the participants especially women is assumed to depend on certain related factors (influencers). An attempt is made to identify the ability of SHGs in empowering women and the factors influencing empowerment.

\section{Review of Literature}

There are various studies in the field of microfinance. Some significant studies referred for the research are:

Manimekalai and Rajeshwari (2002) in their study of SHGs in Tamilnadu found that the women members of SHGs who started their own small businesses like tailoring, animal husbandry, petty shop etc. were contributing more than fifty percent of their earnings to their households. They further observed that though women were supporting the families financially, their voices were not heard in core familial decisions like education and weddings of their children, purchasing assets etc. Lalitha and Nagarajan(2002) observed in that in India, microcredit studies done on self help groups dealing with income generating activities have noted positive profit levels and short payback periods for loans. Earnings generated from such undertakings have been instrumental in increasing the physical wellbeing of the household. Naila Kabeer (1998) observed the effectiveness of credit in addressing the needs and priorities of the poor as well as in empowering women. 
The study reveals the impact of participation in micro enterprise services of the SEWA bank in Ahmedabad. The study also provides preliminary indications of the nature and magnitude of benefits resulting from participation. Kapoor Pramilla (2001) in her study tried to discuss, analyse and answer the challenging questions as to why despite all the efforts and progress made, still there continues to be so much of gender discrimination and what strategies, actions and measures to be undertaken to achieve the expected goal of empowerment. She opined that women's empowerment is much more likely to be achieved if women have total control over their own organisations, which they can sustain both financially and managerially without direct dependence on others.

\section{Objectives of Study}

The study was undertaken with the following objectives:

1. To examine the effectiveness of SHG- as a tool for empowerment.

2. To identify the role of age and education of respondent on empowerment of women through SHGs.

3. To suggest measures for effective and planned empowerment of women.

\section{Sampling Design}

The study is based on sampling technique. The whole of Aurangabad district is included in the study. A sample of 107 SHG members from among the functioning SHGs of Aurangabad district (both urban and rural belts) has been chosen. Due care is taken to ensure representation of entire population. The sampling method hence chosen was random sampling based on convenience to certain extent.

\section{Profile of Aurangabad District}

Aurangabad district includes nine taluka and holds a population of 28,97,013 to its credit as per the 2001 census. The district though one of the leading and developing districts of Marathwada, is yet to come at par with the state values of Human Development Index.

Microfinance is also spreading at a substantial pace within the district. Government agencies along with the NGOs are working unitedly for the benefit. The Swarnajayanti Gram Swarozgar Yojana and the Swarnajayanti Shahari Swarozgar Yojana are implemented within the districts. In the rural areas the SHG-Bank Linkage programme of NABARD is leaving it's mark through the NGOs. Mahila Arthik Vikas Mahamandal is also active in this field. The spread of microfinance is done by these agencies using SHGs as the vehicle. This clearly depicts that quantity wise the establishment of SHGs is done to a large extent in Aurangabad district. An attempt is made to assess the qualitative outcomes of this Group philosophy. 


\section{Methodology and Tools for Data Collection}

The present study is based on survey method. It involves collection of primary data from the SHG-members. The secondary data was collected from various books and articles published in various journals and magazines. In addition different websites were also used for relevant secondary data. The data from the respondents was collected with the help of a structured questionnaire. The pre-post methodology was used to analyse the change in empowerment levels of the sample.

\section{Data Processing}

After collection of the questionnaires, the data was tabulated and analyzed with the help of SPSS, the statistical package. The statistical tools like percentage analysis, cross-factor analysis, chi-square technique were applied.

\section{Measurement of Variables}

The researcher, after a thorough review of studies, has identified four major parameters that indicate empowerment of women as an outcome of SHG-participation. These parameters are then tested through fourteen distinct variables. The change is determined using pre-post methodology. The following are the four parameters considered by the researcher:

1. General Awareness

2. Mobility

3. Decision making

4. Access to resources

\section{Framework of Analysis}

The analysis is undertaken in three sections. The first section deals with the profile of the sample while the second section provides with cross factor analysis. The results of hypothesis testing are presented in the third section.

\section{Limitations of the Study}

The following are the specific limitations of the study:

1. The study was conducted only in the Aurangabad district and the sample size was limited to 107 . Consequently the results cannot be expected to achieve optimum accuracy.

2. Empowerment being a sensitive issue and respondents coming from illiterate and neo-literate categories, it was quiet challenging for the researcher to convince the respondents to part with their personal details.

3. Time and cost constraints were the other limitations of the study. 
4. As the study is based completely on the responses obtained through the questionnaire, the limitations applicable to the questionnaire method affect this study also.

\section{Data Analysis}

The data collected by the researcher was encoded and tabulated. It was further exposed to statistical tools like percentage analysis and chi-square analysis. The results obtained thereof are as summarized below:

\section{Section I}

- The area (Urban/Rural) based distribution of respondents is presented in Chart No.1:

Chart No. 1

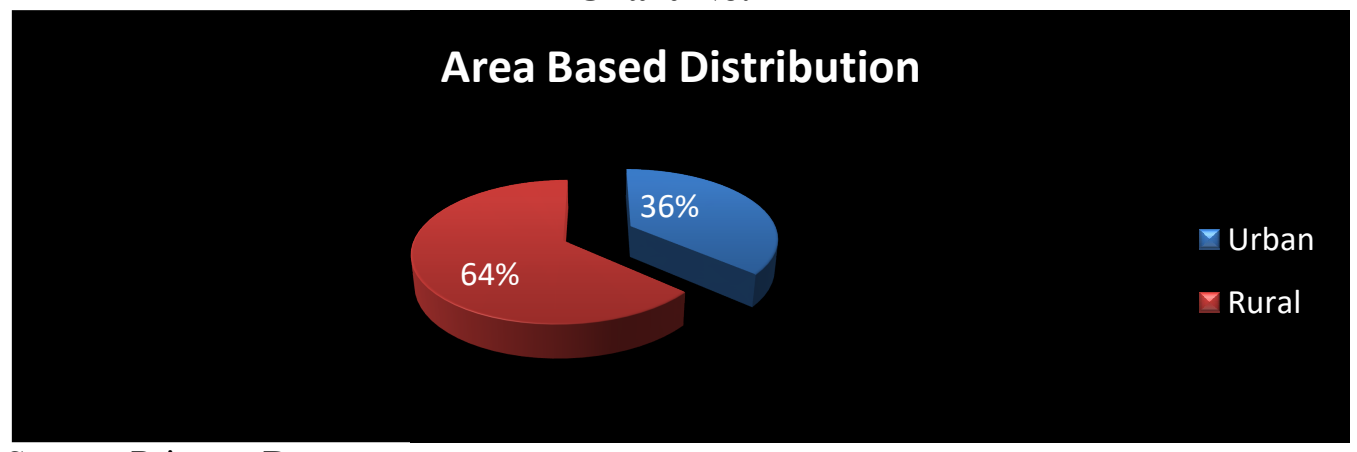

Source: Primary Data

It is clear from chart no. 1 that of the total 107 respondents $64 \%$ are from rural areas of Aurangabad and $36 \%$ of the respondents are from urban areas of Aurangabad.

- The classification of respondents on the basis of their age is given in chart no.2:

Chart No. 2

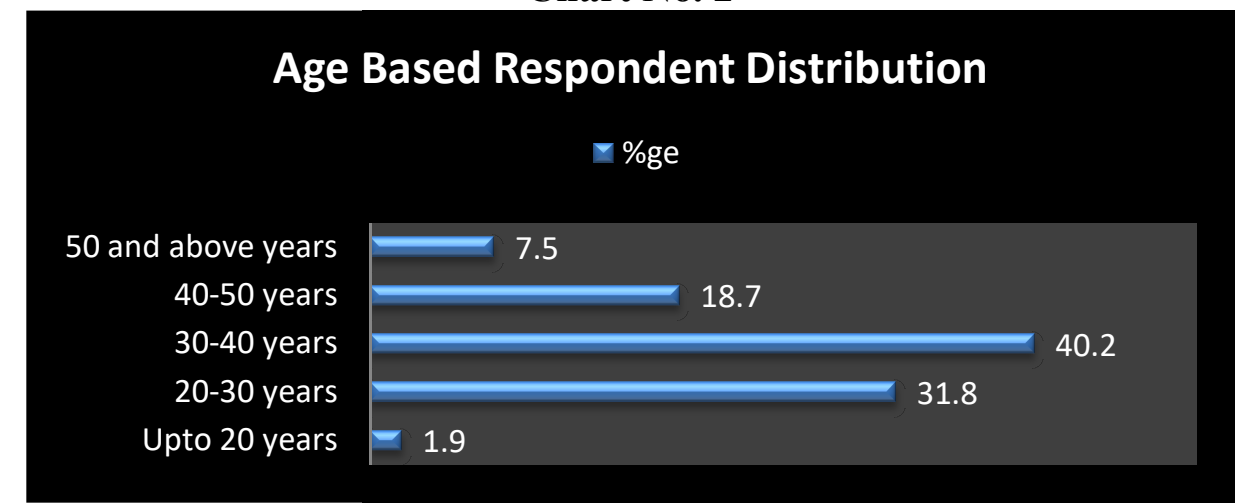

Source: Primary Data 
It is observed from chart no. 2 that $40.2 \%$ of respondents belong to age group 30-40 yrs., $31.8 \%$ belong to $20-30$ yrs., $18.7 \%$ belong to $40-50$ yrs. and $7.5 \%$ belong to 50 yrs. and above. It is also observed that only $1.9 \%$ respondents belong to below 20 years age group. The sample thus holds to it's credit a larger representation of 20-40 years age group $(72 \%)$.

- The Educational levels of respondents are given in chart no. 3 below:

Chart No. 3

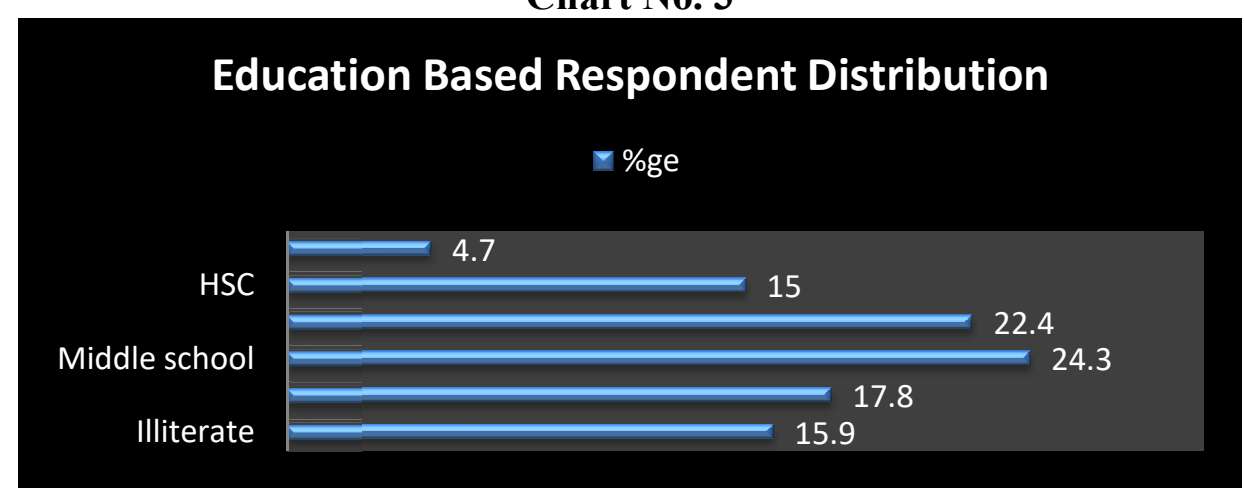

Source: Primary data

Chart no. 3 given above shows that almost $16 \%$ of the respondents are illiterate. $17.8 \%$ respondents have primary education while $24.3 \%$ respondents educated upto middle school. $22.4 \%$ and $15 \%$ of respondents are SSC and HSC respectively. Only $4.7 \%$ respondents are graduate. It is clearly noticed that larger proportion of the respondents is sparsely literate $(42.1 \%)$.

- The distribution of respondents based on marital status is provided in chart no.4 below:

Chart No. 4

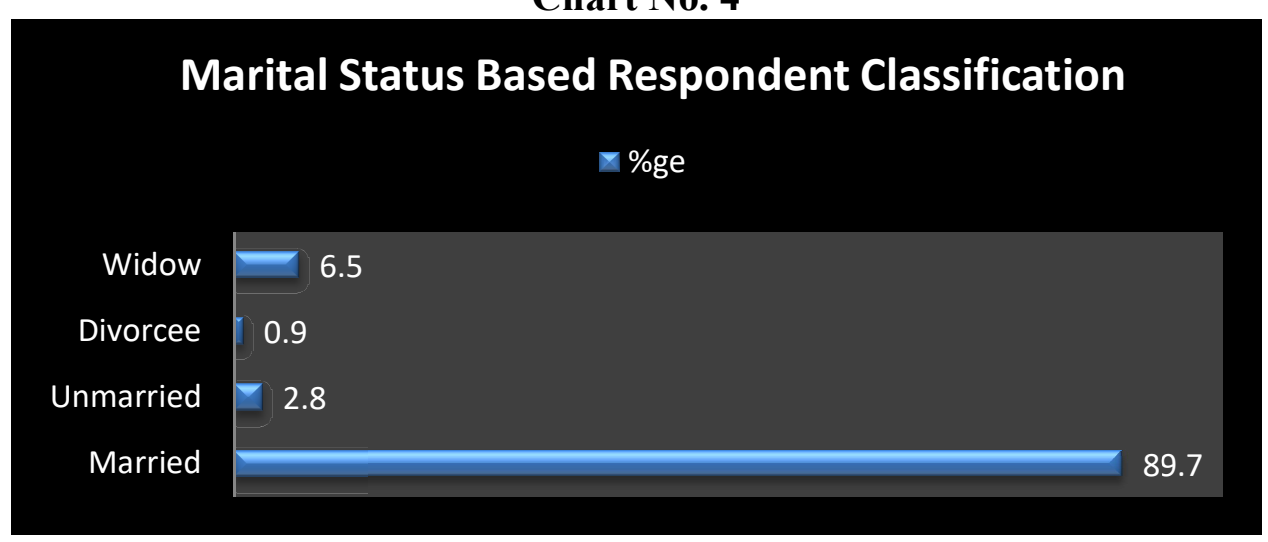

Source: Primary data 
Chart no.4 above shows that majority of the SHG participants are married. It further reflects the participation of widows and divorcees as well. Though less, unmarried women (girls) also form to be a part of the respondent base.

- The distribution of respondents based on occupation is presented in chart no.5 below:

Chart No. 5

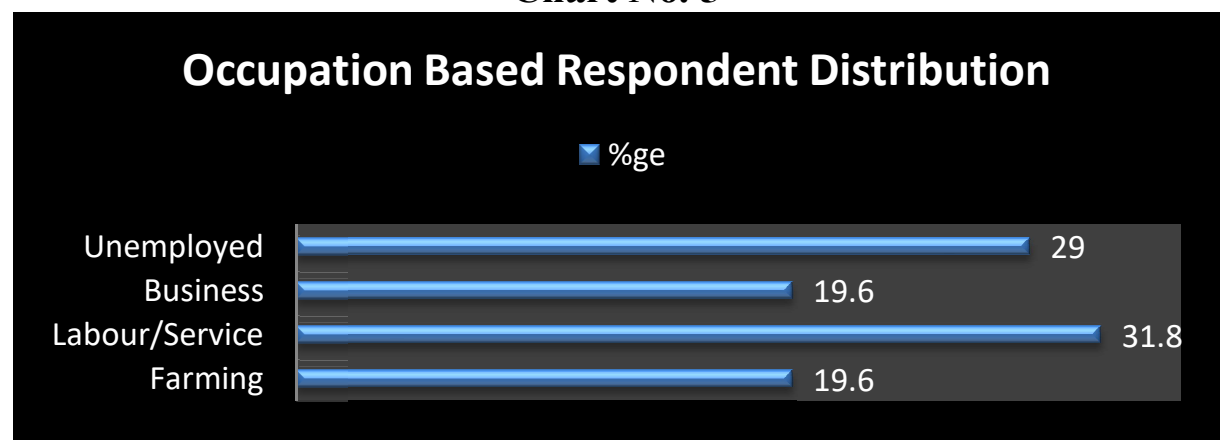

Source: Primary data

The chart above states that a substantial portion of the respondents is unemployed (29\%). $20 \%$ women respondents are farming while $32 \%$ are with occupation of labour/service. $20 \%$ of the total respondents are currently doing business.

\section{Section II}

The respondents are tested on selected parameters for empowerment and the change in empowerment within pre-joining and post joining phases is identified.

\section{Change in General Awareness}

The general awareness of respondents is assumed to be an important factor contributing to the woman's empowerment. The level of general awareness is analysed on the basis of three indicators; habit of reading newspaper, knowledge of child vaccination and knowledge of basic banking transactions. The change therein is depicted in the chart no.6 given below:

\section{Chart No. 6}

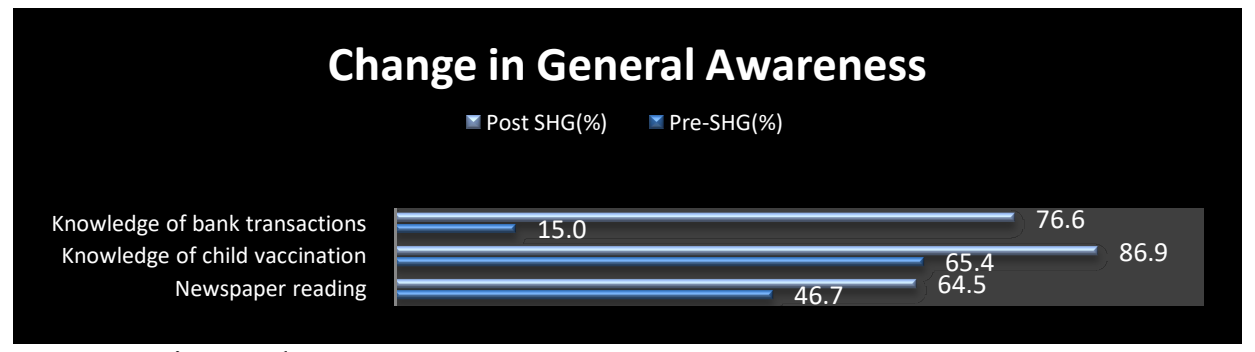

Source: Primary data 
Chart no.6 gives a clear picture about the changes in the state of general awareness of the women respondents after joining SHGs. In connection with the newspaper reading habit of the respondents, before joining SHG $46.7 \%$ of respondents were actively reading newspapers. After joining SHG this percentage increased by almost $18 \%$ to $64.5 \%$. In the pre-SHG phase, $65.4 \%$ women were aware of child vaccination. After joining the SHGs, almost $90 \%$ of the respondents reported of having knowledge of child vaccination. The chart further states that the respondents under study were in a poor state as far as the knowledge of banking transactions was concerned with only $15 \%$ reporting of having knowledge of basic banking transactions. With the membership of SHGs a substantial rise is observed in this proportion, to the extent of $76.6 \%$ of respondents having knowledge of the basic banking transactions.

\section{Change in Mobility}

The second parameter chosen for study was the mobility of the respondents. Again three indicators were selected for assessing the change in mobility; whether the respondent had travelled to another city, town or village, whether she needed permission for travelling and whether she had the ability to travel alone. A comparative analysis of pre-SHG and post-SHG phases is given in chart no. 7 below:

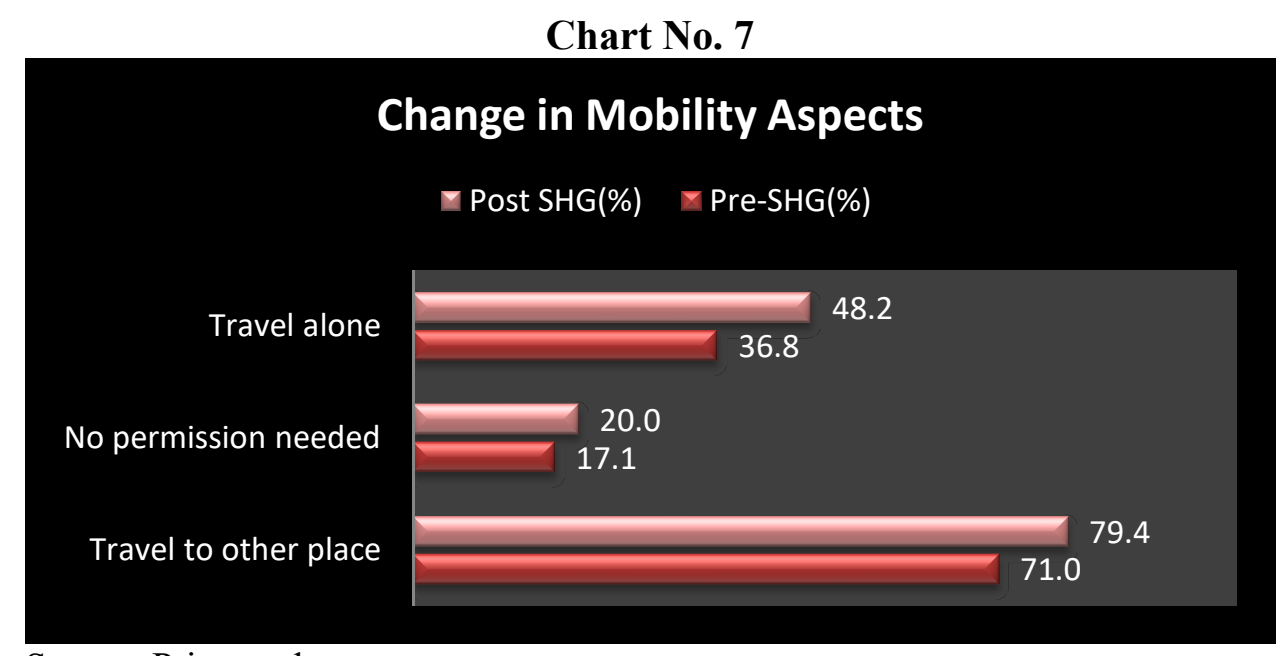

Source: Primary data

The above given chart shows that majority of the respondents $(71 \%)$ were used to travelling out to other city, town or village before being members of SHGs. However after SHG-membership this percentage increased to $79.4 \%$. In the pre-SHG phase, there were only $17 \%$ respondents who could move without seeking permission. In the postSHG phase there is an increase, though marginal (3\%), in the number of respondents not needing to take permission to travel. The ability of the respondents to travel alone is also 
on increase from $36.8 \%$ in pre-SHG phase to $48.2 \%$ in post-SHG phase. Thus, a positive change in the mobility of the respondents is evident.

\section{Change in Household Decision Making}

The role of a woman in decision making is another significant indicator of her empowerment. Her opinion being of some value, in itself infuses confidence in her. It holds a great deal of psychological impact on the woman. To assess the change in role of respondents in household decision making three indicators were used; decisions about small purchases, large purchases and children education. An attempt was made to find out the pattern of decision making followed by the respondents. The responses were gathered on three options, whether decisions were made by self, jointly or by others (husband or in-laws or others). The responses recorded for each of the indicators are presented in chart no.8, 9 and 10 below:

Chart No. 8

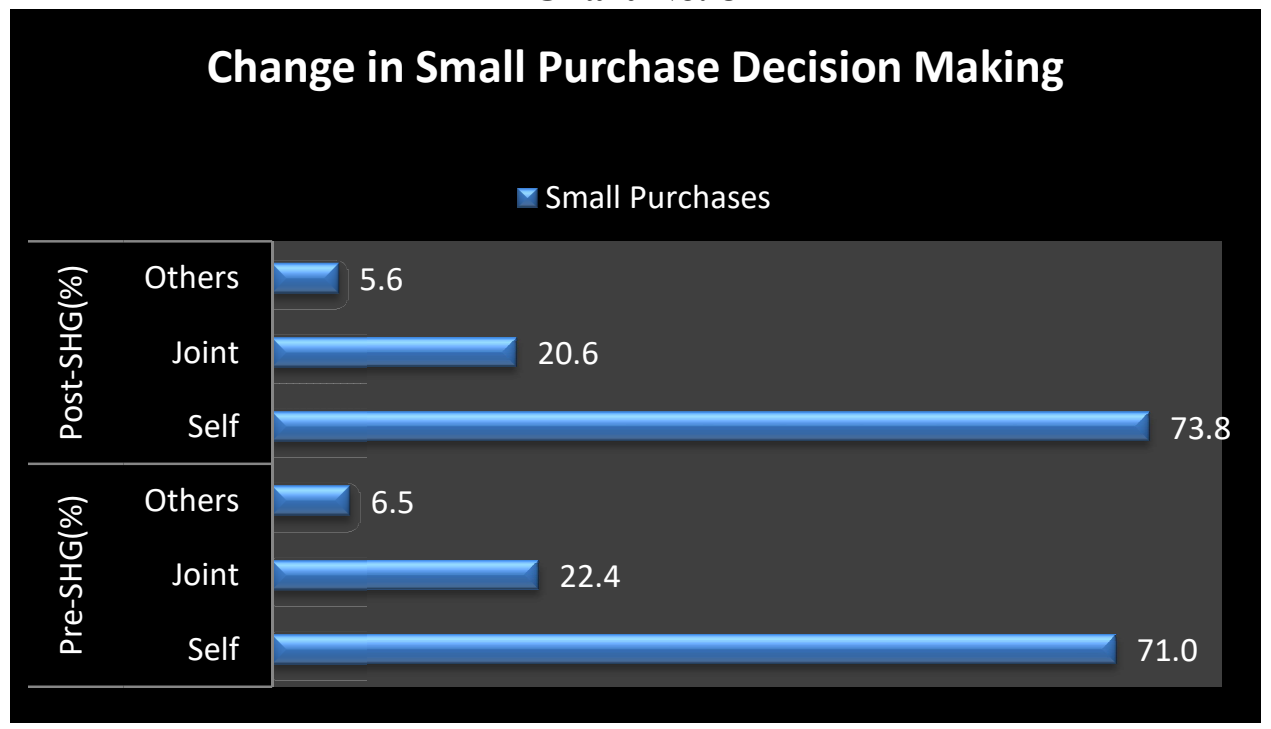

Source: Primary data

The change in role of respondents in small purchase decisions like purchase of vegetables, groceries etc. is observed in chart no.8 above. The respondents have fared well with almost $71 \%$ making self decisions before joining the groups. There is an increase by $3 \%$ in the post SHG period. 


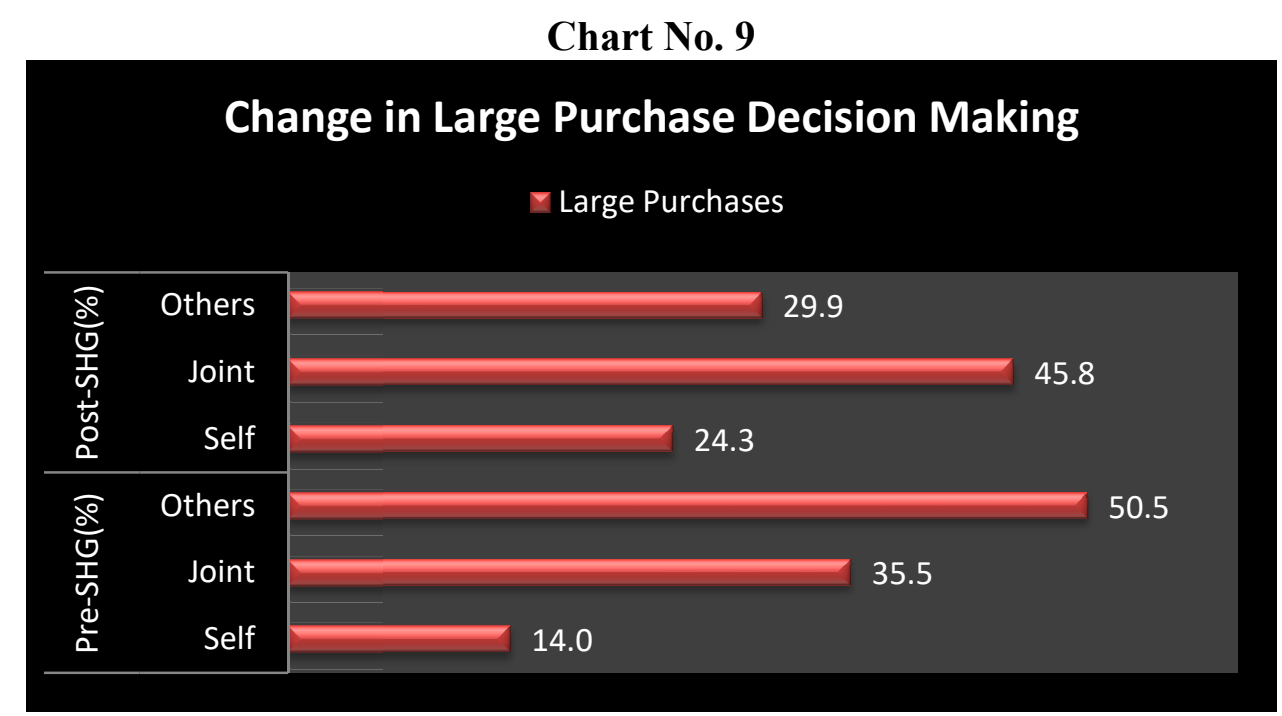

Source: Primary data

The change in large purchase decision making is visible from chart no. 9 above. Prior to joining SHGs only $14 \%$ of the respondents could make decisions on their own, while $35.5 \%$ enjoyed voice in joint decision making. After joining SHGs a better picture is registered with $10 \%$ increase in self decision making (24.3\%). Similarly the consideration of respondent opinion in large purchase decisions is increased to $45.8 \%$. Thus the dictation of others in large purchase decisions has reduced substantially from $50.5 \%$ in pre-SHG phase to $29.9 \%$ in post-SHG phase.

Chart No. 10

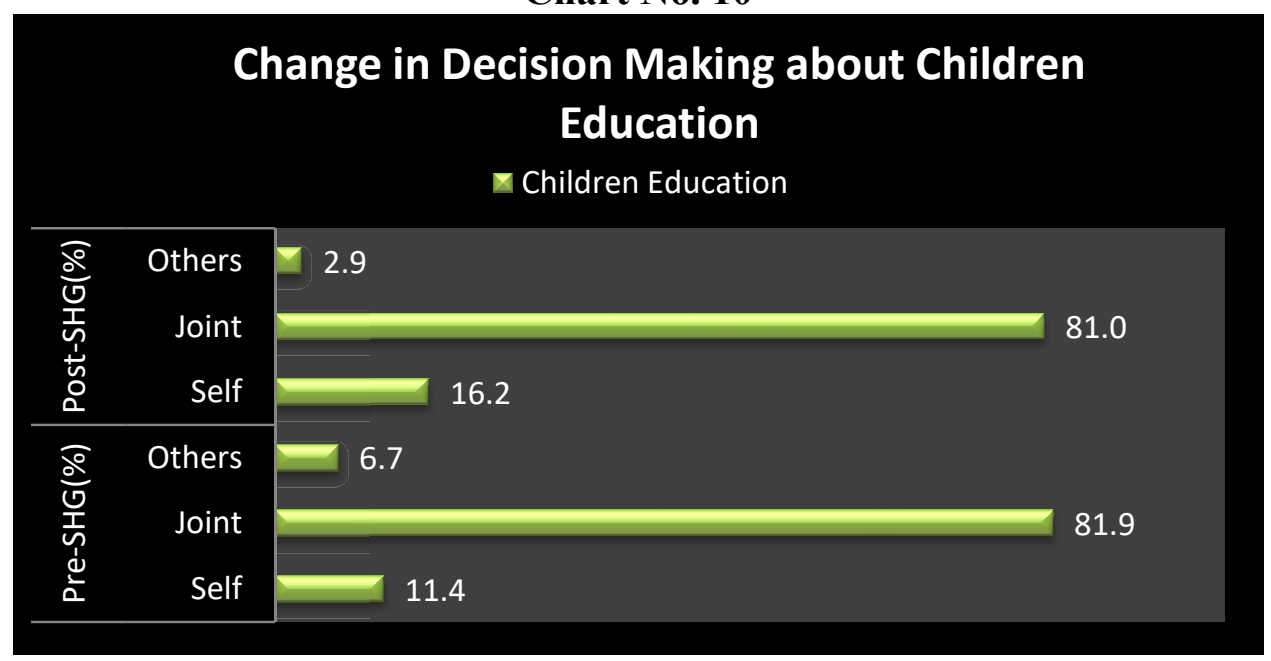

Source: Primary data

Note: Percentages calculated after excluding respondents without children and unmarried 
The role of respondents in decisions about children education is given in chart no. 10 above. It can be observed that the self decision making has increased from meager $11.4 \%$ in pre-SHG phase to $16.2 \%$ in post-SHG phase. Joint decision making is favored both in pre-SHG and post-SHG phases.

\section{Change in Access to Resources}

The fourth parameter is the access to resources. It is believed that empowerment is also governed to a marked extent by an individual's access to resources. The three indicators used are having a bank account (in her own name), having an insurance policy and possessing and using mobile.

\section{Chart No. 11}

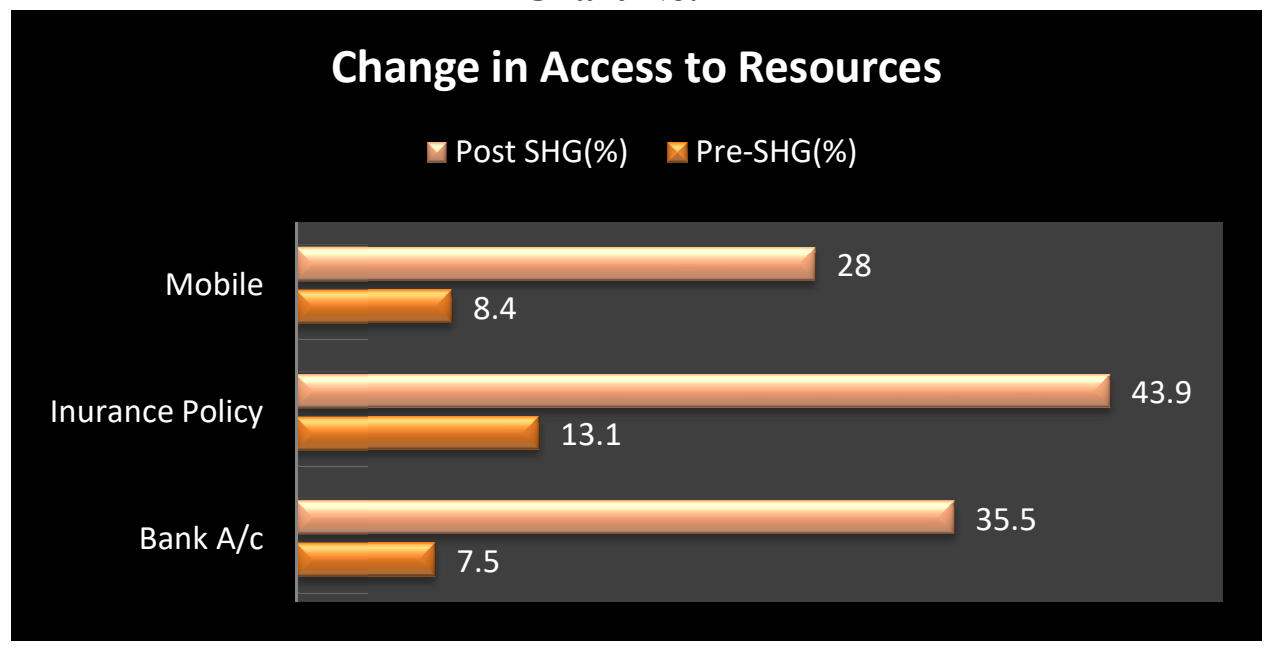

Source: Primary data

The above given chart clearly shows a substantial increase in the number of respondents with a bank account from a meager $7.5 \%$ in pre-SHG stage to $35.5 \%$ in the post-SHG phase. Similarly, only $13 \%$ of the respondents were aware about the value of their lives and had themselves insured in the Pre-SHG phase. This awareness is observed to have increased by almost 30\% after joining SHGs. Usage of mobile is also seen to have increased with $28 \%$ respondents now confident enough to have their mobiles as against only $8.4 \%$ in the pre-SHG phase.

It is thus evident from the analysis given in section II, that participation in SHGs has been beneficial to the respondents. Almost on every indicator they have excelled in their empowerment. The change clearly indicates that SHG-participation is one of the important reasons for change in empowerment of women respondents. 


\section{Section III}

\section{Hypothesis Testing}

This section analyses the role of period of association with the SHG and the education of respondent on empowerment of the respondents. For the purpose certain hypotheses were framed. These hypotheses were then tested using the chi-square test. The consolidated data figures of cross factor analysis for period of association are given in table 1 below:

\section{Table No.1}

Period of Association Empowerment Indicators

\begin{tabular}{|l|l|c|c|c|c|c|c|}
\hline \multirow{4}{*}{ Parameters } & $\begin{array}{l}\text { Period of Association } \\
\text { (Years) }\end{array}$ & \multicolumn{3}{c|}{$\begin{array}{c}\text { Less than Three } \\
\text { Years }\end{array}$} & \multicolumn{3}{c|}{$\begin{array}{c}\text { More than Three } \\
\text { Years }\end{array}$} \\
\cline { 2 - 9 } & Indicators & Yes & No & Total & Yes & No & Total \\
\hline \multirow{4}{*}{$\begin{array}{l}\text { General } \\
\text { Awareness }\end{array}$} & Newspaper Reading & 40 & 18 & 58 & 29 & 20 & 49 \\
\cline { 2 - 9 } & $\begin{array}{l}\text { Knowledge of Child } \\
\text { Vaccination }\end{array}$ & 53 & 5 & 58 & 40 & 9 & 49 \\
\cline { 2 - 9 } & $\begin{array}{l}\text { Knowledge of Bank } \\
\text { Transactions }\end{array}$ & 43 & 15 & 58 & 39 & 10 & 49 \\
\hline \multirow{4}{*}{ Mobility } & Travel & 52 & 6 & 58 & 33 & 16 & 49 \\
\cline { 2 - 9 } & Need Permission & 47 & 5 & 52 & 21 & 12 & 33 \\
\cline { 2 - 9 } & Travel Alone & 20 & 32 & 52 & 21 & 12 & 33 \\
\hline $\begin{array}{l}\text { Household } \\
\text { Making(self) }\end{array}$ & Small Purchases & 37 & 21 & 58 & 42 & 7 & 49 \\
\cline { 2 - 9 } & Large Purchases & 16 & 42 & 58 & 10 & 39 & 49 \\
\cline { 2 - 8 } & Children Education & 10 & 46 & 56 & 7 & 42 & 49 \\
\hline \multirow{2}{*}{$\begin{array}{l}\text { Access to } \\
\text { Resources }\end{array}$} & Bank A/c holding & 11 & 47 & 58 & 27 & 22 & 49 \\
\cline { 2 - 8 } & Insurance policy & 39 & 19 & 58 & 8 & 41 & 49 \\
\cline { 2 - 8 } & Mobile & 17 & 41 & 58 & 13 & 36 & 49 \\
\hline
\end{tabular}

Source: Primary data

On the basis of the above given data four hypotheses were put to test. The results of these tests and inferences drawn thereof are presented as follows:

\section{Hypothesis 1:}

$\mathrm{H}_{0}$ : There is no significant relationship between period of association of respondent with SHG and level of general awareness of respondent.

An attempt was made by researcher to find whether period of association of respondent with the SHG and her general awareness were related with each other. The analysis was done using chi-square test. The calculations are given in table 2 below: 
Table No.2

Relationship between Period of Association and General Awareness

\begin{tabular}{|c|l|c|c|c|c|}
\hline Sr. No. & \multicolumn{1}{|c|}{ Indicator } & $\begin{array}{c}\text { Calculated } \\
\text { Value } \mathbf{( X}^{\mathbf{2}}\end{array}$ & $\mathbf{D f}$ & $\begin{array}{c}\text { Table Value } \\
\mathbf{( 5 \%} \text { sig.) }\end{array}$ & Inference \\
\hline 1. & Newspaper Reading & 1.11 & 1 & 3.841 & Insignificant \\
\hline 2. & $\begin{array}{l}\text { Knowledge of Child } \\
\text { vaccination }\end{array}$ & 2.219 & 1 & 3.841 & Insignificant \\
\hline 3. & $\begin{array}{l}\text { Knowledge of Bank } \\
\text { transactions }\end{array}$ & 0.441 & 1 & 3.841 & Insignificant \\
\hline
\end{tabular}

Source: Calculated by researcher

It is clear from the above table that general awareness of respondent is independent of the period of association with the group.

\section{Hypothesis 2:}

$\mathrm{H}_{0}$ : There is no significant relationship between period of association of respondent with SHG and mobility level of respondent.

Table No.3

Relationship between Period of Association and Mobility

\begin{tabular}{|l|l|c|c|c|c|}
\hline Sr. No. & \multicolumn{1}{|c|}{ Indicator } & $\begin{array}{c}\text { Calculated } \\
\left.\text { Value } \mathbf{( X}^{\mathbf{2}}\right)\end{array}$ & $\mathbf{D f}$ & $\begin{array}{c}\text { Table Value } \\
\mathbf{( 5 \%} \text { sig.) }\end{array}$ & Inference \\
\hline 1 & Travel & 8.093 & 1 & 3.841 & Significant \\
\hline 2 & Permission not needed & 9.028 & 1 & 3.841 & Significant \\
\hline 3 & Travel alone & 5.124 & 1 & 3.841 & Significant \\
\hline
\end{tabular}

Source: Calculated by researcher

Table no.3 above states that the period of association with the SHG and ability of the respondent to travel to other city, town or village are related significantly. It is also found that the necessity of permission to travel out and period of association with SHG are not independent of each other. The ability of the respondent to travel alone is also related significantly with her period of association with the SHG. Thus it may be inferred that period of association with the SHG and mobility of the respondents is related significantly with each other.

\section{Hypothesis 3:}

$\mathrm{H}_{0}$ : There is no significant relationship between period of association of respondent with SHG and self decision making of respondent. 
Table No.4

Relationship between Period of Association and Self Decision Making (Household)

\begin{tabular}{|l|l|c|c|c|c|}
\hline Sr. No. & \multicolumn{1}{|c|}{ Indicator } & $\begin{array}{c}\text { Calculated } \\
\text { Value }\left(\mathbf{X}^{\mathbf{2}}\right)\end{array}$ & Df & $\begin{array}{c}\text { Table Value } \\
\mathbf{( 5 \%} \text { sig. })\end{array}$ & Inference \\
\hline 1 & Small purchases & 6.606 & 1 & 3.841 & Significant \\
\hline 2 & Large purchases & 0.744 & 1 & 3.841 & Insignificant \\
\hline 3 & Children education & 0.246 & 1 & 3.841 & Insignificant \\
\hline
\end{tabular}

Source: Calculated by researcher

From table no.4 it is clear that there is significant relationship between period of association and small purchase decision making. However, no such relationship is observed for large purchase decision making and decisions regarding children education.

\section{Hypothesis 4:}

$\mathrm{H}_{0}$ : There is no significant relationship between period of association of respondent with SHG and access to resources of respondent.

Table No.5

Relationship between Period of Association and Access to Resources

\begin{tabular}{|l|l|c|c|c|c|}
\hline Sr. No. & \multicolumn{1}{|c|}{ Indicator } & $\begin{array}{c}\text { Calculated } \\
\left.\text { Value } \mathbf{( X}^{2}\right)\end{array}$ & Df & $\begin{array}{c}\text { Table Value } \\
\mathbf{( 5 \%} \text { sig. })\end{array}$ & Inference \\
\hline 1 & Bank Account & 15.145 & 1 & 3.841 & Significant \\
\hline 2 & Insurance policy & 27.954 & 1 & 3.841 & Significant \\
\hline 3 & Mobile & 0.102 & 1 & 3.841 & Insignificant \\
\hline
\end{tabular}

Source: Calculated by researcher

Table no.5 shows the calculated values and tabulated values of chi-square for each of the empowerment indicator regarding access to resources. It is observed that the period of association is related with the possession of bank account and insurance policy of the respondent in her own name. However, the possession and usage of mobile is independent of the period of association with the SHG.

The second factor assessed as an influencer is the education of the respondents. The cross factor analysis between education of respondent and empowerment indicators is given in table 6 below: 
Table No.6

Education of Respondent Empowerment Indicators

\begin{tabular}{|c|c|c|c|c|c|c|c|c|c|c|c|c|c|c|c|c|c|c|c|}
\hline \multirow[t]{2}{*}{ Parameter } & \multirow{2}{*}{\begin{tabular}{c}
\multicolumn{1}{c}{$\begin{array}{c}\text { Period of } \\
\text { Association(Years) }\end{array}$} \\
Indicators
\end{tabular}} & \multicolumn{3}{|c|}{ Illiterate } & \multicolumn{3}{|c|}{$\begin{array}{l}\text { Primary } \\
\text { School }\end{array}$} & \multicolumn{3}{|c|}{ Middle School } & \multicolumn{3}{|c|}{ SSC } & \multicolumn{3}{|c|}{ HSC } & \multicolumn{3}{|c|}{ Graduate } \\
\hline & & $\mathrm{Y}$ & $\mathrm{N}$ & $\mathrm{T}$ & $\mathrm{Y}$ & $\mathrm{N}$ & $\mathrm{T}$ & $\mathrm{Y}$ & $\mathrm{N}$ & $\mathrm{T}$ & $\mathrm{Y}$ & $\mathrm{N}$ & $\mathrm{T}$ & $\mathrm{Y}$ & $\mathrm{N}$ & $\mathrm{T}$ & $\mathrm{Y}$ & $\mathrm{N}$ & $\mathrm{T}$ \\
\hline \multirow{3}{*}{$\begin{array}{l}\text { General } \\
\text { Awareness }\end{array}$} & Newspaper Reading & 1 & 16 & 17 & 9 & 10 & 19 & 19 & 7 & 26 & 21 & 3 & 24 & 14 & 2 & 16 & 5 & 0 & 5 \\
\hline & $\begin{array}{l}\text { Knowledge of Child } \\
\text { Vaccination }\end{array}$ & 11 & 6 & 17 & 16 & 3 & 19 & 24 & 2 & 26 & 21 & 3 & 24 & 16 & 0 & 16 & 5 & 0 & 5 \\
\hline & $\begin{array}{l}\text { Knowledge of Bank } \\
\text { Transactions }\end{array}$ & 10 & 7 & 17 & 12 & 7 & 19 & 21 & 5 & 26 & 20 & 4 & 24 & 14 & 2 & 16 & 5 & 0 & 5 \\
\hline \multirow{3}{*}{ Mobility } & Travel & 12 & 5 & 17 & 13 & 6 & 19 & 23 & 3 & 26 & 19 & 5 & 24 & 13 & 3 & 16 & 5 & 0 & 5 \\
\hline & Need Permission & 9 & 3 & 12 & 8 & 5 & 13 & 23 & 0 & 23 & 17 & 2 & 19 & 9 & 4 & 13 & 2 & 3 & 5 \\
\hline & Travel Alone & 10 & 2 & 12 & 7 & 6 & 13 & 8 & 15 & 23 & 6 & 13 & 19 & 5 & 8 & 13 & 5 & 0 & 5 \\
\hline \multirow{3}{*}{$\begin{array}{l}\text { Household } \\
\text { Decision } \\
\text { making } \\
\text { (self) }\end{array}$} & Small Purchases & 16 & 1 & 17 & 15 & 4 & 19 & 19 & 7 & 26 & 13 & 11 & 24 & 11 & 5 & 16 & 5 & 0 & 5 \\
\hline & Large Purchases & 9 & 8 & 17 & 5 & 14 & 19 & 3 & 23 & 26 & 3 & 21 & 24 & 5 & 11 & 16 & 1 & 4 & 5 \\
\hline & Children Education & 7 & 10 & 17 & 5 & 14 & 19 & 1 & 25 & 26 & 2 & 22 & 24 & 2 & 13 & 15 & 0 & 4 & 4 \\
\hline \multirow{3}{*}{$\begin{array}{l}\text { Access to } \\
\text { resources }\end{array}$} & Bank A/c holding & 8 & 9 & 17 & 9 & 10 & 19 & 9 & 17 & 26 & 5 & 19 & 24 & 3 & 13 & 16 & 4 & 1 & 5 \\
\hline & Insurance policy & 4 & 13 & 17 & 6 & 13 & 19 & 12 & 14 & 26 & 13 & 11 & 24 & 10 & 6 & 16 & 2 & 3 & 5 \\
\hline & Mobile & 1 & 16 & 17 & 8 & 11 & 19 & 6 & 20 & 26 & 4 & 20 & 24 & 6 & 10 & 16 & 5 & 0 & 5 \\
\hline
\end{tabular}

Source: Primary data

\section{Hypothesis 5:}

$\mathrm{H}_{0}$ : There is no significant relationship between education of respondent and level of general awareness of respondent.

An attempt was made by researcher to find whether education of respondent and her general awareness were related with each other. The analysis was done using chi-square test.

Table No.7

Relationship between Respondent Education and General Awareness

\begin{tabular}{|l|l|c|c|c|c|}
\hline Sr. No. & \multicolumn{1}{|c|}{ Indicator } & $\begin{array}{c}\text { Calculated } \\
\text { Value }\left(\mathbf{X}^{\mathbf{2}}\right)\end{array}$ & $\mathbf{D f}$ & $\begin{array}{c}\text { Table Value } \\
(\mathbf{5 \%} \text { sig.) }\end{array}$ & Inference \\
\hline 1 & Newspaper Reading & 40.77 & 5 & 11.07 & Significant \\
\hline 2 & $\begin{array}{l}\text { Knowledge of Child } \\
\text { vaccination }\end{array}$ & 11.33 & 5 & 11.07 & Significant \\
\hline 3 & $\begin{array}{l}\text { Knowledge of Bank } \\
\text { transactions }\end{array}$ & 8.37 & 5 & 11.07 & Insignificant \\
\hline
\end{tabular}

Source: Calculated by researcher

Table no.7 indicates that habit of reading newspaper and knowledge of child vaccination are significantly related with the education of the respondent. On the other hand, quiet surprisingly, no relationship is observed between education of respondent and knowledge of basic banking transactions. The reason mainly may be related with the fact that after joining SHG, each and every member of the group is well acquainted with the concept of banking. 


\section{Hypothesis 6:}

$\mathrm{H}_{0}$ : There is no significant relationship between education of respondent and mobility level of respondent.

\section{Table No.8}

Relationship between Respondent Education and Mobility Level

\begin{tabular}{|l|l|c|c|c|c|}
\hline Sr. No. & \multicolumn{1}{|c|}{ Indicator } & $\begin{array}{c}\text { Calculated } \\
\text { Value }\left(\mathbf{X}^{\mathbf{2}}\right)\end{array}$ & Df & $\begin{array}{c}\text { Table Value } \\
\mathbf{( 5 \%} \text { sig. })\end{array}$ & Inference \\
\hline 1 & Travel & 4.85 & 5 & 11.07 & Insignificant \\
\hline 2 & Permission not needed & 15.71 & 5 & 11.07 & Significant \\
\hline 3 & Travel alone & 15.73 & 5 & 11.07 & Significant \\
\hline
\end{tabular}

Source: Calculated by researcher

It is observed from table no.8 that education of respondent and ability to travel are independent. However, the ability to travel alone and the necessity of permission for travelling are influenced by the education of the respondent.

\section{Hypothesis 7:}

$\mathrm{H}_{0}$ : There is no significant relationship between education of respondent and self decision making of respondent.

Table No.9

Relationship between Respondent Education and Self Decision Making (Household)

\begin{tabular}{|l|l|c|c|c|c|}
\hline Sr. No. & \multicolumn{1}{|c|}{ Indicator } & $\begin{array}{c}\text { Calculated } \\
\left.\text { Value } \mathbf{( X}^{\mathbf{2}}\right)\end{array}$ & Df & $\begin{array}{c}\text { Table Value } \\
\mathbf{( 5 \%} \text { sig.) }\end{array}$ & Inference \\
\hline 1 & Small purchases & 10.67 & 5 & 11.07 & Insignificant \\
\hline 2 & Large purchases & 12.21 & 5 & 11.07 & Significant \\
\hline 3 & Children education & 14.13 & 5 & 11.07 & Significant \\
\hline
\end{tabular}

Source: Calculated by researcher

From the above given calculations, it is observed that respondent education holds significant influence on self decision making about large purchases and children's education. On the contrary, the respondent education and small purchase decision making are independent of each other.

\section{Hypothesis 8:}

$\mathrm{H}_{0}$ : There is no significant relationship between education of respondent and access to resources of respondent. 
Table No.10

Relationship between Respondent Education and Access to Resources

\begin{tabular}{|l|l|c|c|c|c|}
\hline Sr. No. & \multicolumn{1}{|c|}{ Indicator } & $\begin{array}{c}\text { Calculated } \\
\text { Value }\left(\mathbf{X}^{\mathbf{2}}\right)\end{array}$ & Df & $\begin{array}{c}\text { Table Value } \\
(\mathbf{5 \%} \text { sig.) }\end{array}$ & Inference \\
\hline 1 & Bank Account & 10.71 & 5 & 11.07 & Insignificant \\
\hline 2 & Insurance policy & 7.39 & 5 & 11.07 & Insignificant \\
\hline 3 & Mobile & 21.39 & 5 & 11.07 & Significant \\
\hline
\end{tabular}

Source: Calculated by researcher

It may be inferred from table 10 above that education of respondent is found to have significant relationship with the access to mobiles. There is no significant relationship between respondent education and bank account holding and possession of insurance policy.

\section{Findings of the Study}

The findings of the study are presented as follows:

1. It is well understood that the concept of Self Help Groups is spread in both rural as well as urban areas.

2. Women from all age groups find representation in the SHGs. It may be noted that majority of the women participating in SHGs are middle aged ranging between 20-40 years.

3. The group mechanism is not restricted only to literate class of the society. Instead the illiterate women form to be an important component of these SHGs. However, the well educated women need be motivated to form such groups and reap the benefits thereof.

4. It is also seen that majority of the respondents are married $(88 \%)$. It must be appreciated that though in sparse proportion, widows and divorcees are also becoming members of SHGs. Infact; such women are more disempowered on the grounds of the circumstances and hence are in need of group support. This surely is an encouraging trend.

5. SHGs are not a domain of employed women alone. Both employed and unemployed women are members of SHGs. This in itself speaks of the benefits of SHGs attracting the non-earning women.

6. With SHG joining, the women have developed habit of reading newspaper. This keeps them better informed about the developments taking place in the surrounding world.

7. Knowledge of child vaccination is also found to have spread largely through SHGparticipation. It is thus creating health awareness among the women.

8. The main purpose of SHGs is meeting the financial needs of the members and extending banking services to the unbanked population. This purpose is being served 
to a large extent. The number of respondents having knowledge of basic banking transactions has increased by five times in the post-joining phase.

9. Women in general and rural women in particular face restrictions in their mobility. It is also observed that if they are mobile it is with permission of others (like husband, in-laws etc.). However, after becoming a member of SHG, the respondents have reported positive changes in the mobility related aspects. The percentage of women needing permission to travel has reduced considerably. Also the women have become more confident and are now travelling alone.

10. Women have shared a relatively negligible space in decision making within the households. For making small purchases, considerable number of respondents made decisions on their own before joining SHGs. This percentage however, increased after joining SHGs. In case of large purchase decisions however, husbands and other members of the family dominated largely. Only $14 \%$ of the sample respondents did enjoy the freedom of making large purchases on their own in the pre-SHG phase. This percentage increased to almost $25 \%$ in the post SHG phase. Also women participated in joint decision making largely after joining SHGs. This shows that after joining SHGs the women attained a better say in their household decisions.

11. Commendable increase (almost five times) is observed in the percentage of respondents having bank accounts after joining SHGs. This shows that the women are shedding away their shyness and are accessing the benefits of banking services.

12. It is being realized by the respondents that their life is equally valuable as of their husbands and children. This is clear from the increase in the percentage of respondents $(30 \%)$ having insurance policies.

13. These respondents are making use of modern technology in the form of mobile phones. This is making the members more confident.

14. Empowerment is influenced to a certain extent by the period of association of members with the SHG as well as the education of the respondents.

15. On some matters however, the periodicity of membership as well as education of respondent are found to have no role in empowerment.

\section{Recommendations}

Based on the study following recommendations are made:

- Benefits of SHG participation should be brought to light to motivate the nonparticipants.

- Proper orientation of the family members of the SHG-members shall act as a support for their participation.

- Sustainability of the groups should be a point of focus of the promoting agencies.

- The SHG activities should explore the entrepreneurial potential of the members.

- Self Help Groups should be converted into Self Enterprising Groups. 
- Education shall surely add to the empowerment of women. Hence through SHGs education should be provided to the women.

- The insurance companies should design specialized need based insurance products for these women.

- The banks must motivate the women members to have direct linkage with them.

\section{Conclusion}

On the basis of the study it may be concluded that Self Help Groups are providing a viable platform for empowerment of women. The SHG-participants under study are benefitted to a visible extent from the group philosophy. However, the sustainability of the groups need be focussed for better empowerment. Self Help Groups do have the potential of acting as change agents.

\section{References}

Gladis, M. J. (2008) Women's Empowerment Through Self Help Groups, Southern Economist, Vol.46, No.21, March.

Kabeer N. (1998) 'Money Can't Buy Me Love? Re-Evaluating Gender, Credit And Empowerment In Rural Bangladesh', Discussion Paper No.363, Brighton, U.K.: Institute Of Development Studies.

Kapoor, P. (2001) Empowering the Indian Women, Publications Division, Ministry of Information and Broadcasting, Government of India.

Lalitha N. \& Nagarajan B.S. (2002) Self Help Groups in Rural Development, Dominant Publishers and Distributors, New Delhi.

Manimekalai N. \& Rajeshwari G. (2002) 'Grassroots entrepreneurship through Self Help Groups', SEDME.

Dr. Aparna Bhonde-Saraf is Assistant Professor in the Department of Commerce, Maulana Azad College, Dr.Rafiq Zakaria Campus, Aurangabad, Maharashtra State, India. 